\title{
SOCIAL PROBLEMS OF THE DIABETIC
}

\author{
By IrIs Holland Rogers \\ Welfare Secretary, British Diabetic Association
}

Social problems are often particularly in evidence in the case of the diabetic, and their solution may well be the key to successful treatment. Since the diabetic must live with diabetes, not for a few years but for a life-time, it is of the utmost importance, for his own sake and for that of the community in which he lives, to help him face and conquer his problems, whether they arise directly from the disability itself, are conjured up through ignorance or by his own attitude to his disease, or imposed on him by an uninformed public. Of these, problems induced by ignorance and his own attitude, moral and intellectual, are likely to loom largest, to be the mountain barriers to successful living.

Nowadays, in view of the great advances made in the diabetic field over the last 35 years, it is usual to describe a diabetic's life as 'normal': that is subject to the usual social problems but not to extra or special ones. The existence of the British Diabetic Association would seem to contradict this description since it has come into being just because there are special problems. Perhaps it would be true to say that with sufficient education, intelligence, common-sense, a right attitude both on the part of the diabetic and the community at large, and, in addition, suitable conditions as far as home, background, financial circumstances and work are concerned, the diabetic's life could be very near normal, though a special regime has to be followed faithfully. But these qualities in combination are rare-few of them rarer than ' common' sense-and conditions are seldom ideal. The diabetic is an individual, subject to all sorts of variations in his day-to-day life: uplifted with emotion, cast down by a common cold, perhaps overworked one week and slack the next, struggling to make ends meet or burdened with difficulties at home. While in theory he can be balanced so precisely from the medical point of view that the result is a completely normal person, in reality he will be unlikely to achieve this ideal although many may come near to it.

We are dealing, therefore, with a real person who has developed a lifelong disease. What must he do? He must learn much that is alien to former habits, in fact a new way of life. He is faced with a disease which can be controlled but not cured. Without medical knowledge himself he must understand the reasons for the prescribed treatment and, starting from the bottom rung of the ladder, he must reach up to new attitudes and new habits. Since he must live with his disability for a lifetime, he must learn to be independent even though his doctor is supporting him in the background. No doctor can live his life for him, no wife, no loving friend: he must be master of his ship. Anything less than this may spell failure.

\section{The Child}

Even the diabetic child must be master of his ship in so far as the natural limitations of childhood allow this. At an early age he can be taught to give his own injections, choose suitable foods and take part in the planning of his day-to-day life. It is surprising to witness how often his skill and his morale rise to the occasion. His attitude and that of his parents can make or mar his childhood and through it his future, too. At one time there was no future for the diabetic child, but with the discovery of insulin in 1921 many of the terrors disappeared, and now diabetic children are able to lead healthy lives, grow up into good citizens and play their full part in the world. They can, however, only achieve this prospect, apart from lucky chance, when there has been good training of mind, body and spirit so that problems on all levels can be met and overcome. Although the diabetic child, like all others, needs the love and devotion of parents, it is important that these blessings should not be pushed to the point where they become evils and the child spoilt. For some, the temptation may well be too great not to take advantage of over-loving parents by using the diabetic condition as a weapon of blackmail. The child needs to recognize early in life the value of training and self control. His happiness and wellbeing, even more than in the case of other children, will depend on a judicious tempering of discipline with affection, and of care with encouragement toward independence. 
It was in I939, at the outbreak of war, that the British Diabetic Association was made particularly aware of the problems presented by child diabetics. During the evacuation it was found that no special arrangement had been made for them in the London area: accordingly the Association, in co-operation with the L.C.C., organized their evacuation to a special unit at Hutton Residential School in Essex. Such was the success of this unit that in time the L.C.C. began to receive applications for children in the provinces, not based on the emergency situation of war, but on the specific needs of diabetics in home surroundings where these needs could not adequately be met. Some parents with large families, with low intelligence, or negligent in their care of children found the burden of diabetic treatment too heavy. The unit at Hutton provided the answer in these cases. After the war it became apparent that there were too many children needing this care for them all to be accommodated in the one unit at Hutton.

As a result of questions raised by the B.D.A., a survey was made by the Ministry of Education: they found that there were some 1,200 diabetic school children in the country, of whom about 160 needed special care which could only be provided in residential hostels. In view of these findings the B.D.A. co-operated with the Ministry of Education and childrens' voluntary societies and, in due course, special hostels were opened by the Church of England Children's Society at Kingsdown in Kent, at Rustington in Sussex, and at Kersal near Manchester, and by the National Children's Home at Frodsham in Cheshire. A few years later the L.C.C. moved the Hutton unit to Hammersmith in the London area. Further steps to help with problems presented by the diabetic child were achieved with the opening of holiday camps in $195^{2}$ by the B.D.A. with the approval of the Ministry of Education. Camps give the children a good holiday and their parents a much-needed rest. In addition they provide training in the diabetic way of life, easily accepted by the child in company with other children with the same basic needs and limitations.

\section{Adolescence}

Adolescence can be a difficult period, often a time of rebellion against parents and others in authority. The foundations of the diabetic's training will already have been laid for better or worse and will certainly have an effect on the new problems he will meet. To the newly diagnosed adolescent, diabetes may come as a heavy blow, apparently blocking the way to many of the hopes and plans already shaping for his future. At this stage his thoughts of a career are of paramount im- portance to him. As a step towards defining and widening the possibilities of suitable jobs, the Medical Advisory Committee of the British Diabetic Association has prepared a guide for medical officers when giving advice on employment of diabetic children, and this has now been approved by the Ministry, of Education. It reads as follows:-

'The great majority of occupations can safely be undertaken by the young diabetic and it is therefore easier to consider those which are unsuitable. Regular meals and insulin injections form the basis of good control of diabetes, and occupations in which these cannot reasonably be maintained are unsuitable. This will rule out most forms of shift work, jobs in which the hours of work and meal times are subject to considerable variation, and occupations in which physical exertion is severe and also variable. The other group of occupations unsuitable for diabetics on insulin is that in which the consequence of a hypoglycaemic attack may be serious to themselves or other people. In this category must be included the driving of public transport vehicles, such as trains and buses, signal operating, steeple-jacking, window-cleaning and occupations connected with dangerous machinery. Diabetics are not accepted by the fighting services and the Merchant Service is not well suited to the requirements of the diabetic.

"These suggestions apply to " average" dia betics-using the term " average" to cover both severity of the diabetes and the patient's intelligence and understanding of his condition. There are a number of diabetics engaged in some at least of the occupations listed above and carrying out their duties both safely and successfully.'

Nevertheless, however wide the choice of job given to a diabetic, he may still be excluded from the one occupation that appeals to his heart: not a soldier or a sailor, but a tinker or a tailor.' With his own will to succeed and the help of those interested in his problem-his parents and friends, his doctor, the B.D.A., the Youth Employment Service, After Care and other voluntary and State organizations-he may still lead a full, happy and useful life although he has accepted what at first seems only second best.

Sometimes, in spite of help and the will to succeed, there are difficulties in getting a job, particularly when superannuation is involved. Some doctors advise diabetic patients to register as disabled so that those employers who are obliged to have a quota of employees in this category will accept diabetics: indeed, not only accept them, but accept them with pleasure since a diabetic employee, provided he has the brains and ability for the job in hand, may be the reverse of a liability. 
When speaking of employment, it is as well to remember that diabetes can provide the lazy and unemployable with a most convenient excuse for malingering. It will not help the individual diabetic to encourage self-indulgence and it may well prejudice employers against other diabetics who are conscientious and hard working.

\section{Emigration}

The diabetic, along with many other young people, may wish to emigrate. The immigration authorities judge each case on individual merits but in practice the diabetic is not admitted freely, particularly to Australia where there is a National Health Service on which he might become a charge. Indeed, before 1957 diabetes was a proscribed disease under the Immigration Act in that country. Perhaps the representations made by the Australian Diabetic Association on behalf of the diabetic immigrant have helped to ameliorate government policy in this respect.

\section{Marriage}

In marriage the diabetic's choice is not entirely free, at least from the genetic point of view, since the disease may be inherited. If he falls in love with a member of a family free from diabetes, her parents may nonetheless be reluctant to see her linked to a husband with an incurable disease. Even if they are too polite to put this into words, there may be a distressing feeling of tension to mar the felicity of the occasion. If it can be shown by example that a diabetic can hold his own in the world, opposition may be overcome and support won.

Once married the young couple's thoughts turn to founding a family. Often there will be no difficulties in their way. However, if it is the wife who is the diabetic, she may have been advised not to undergo pregnancy for some special reason or, if both husband and wife are diabetic, the genetic risk may be too great. Thus the question of adoption arises.

\section{Adoption}

Since the supply of babies for adoption is unequal to the demand, adoption societies, whose primary interest is to protect the baby, may well refuse to accept parents who show less than the very highest standard of health. Diabetics may, of course, be well stabilized, vigorous and fit, but, since diabetes is known as an incurable disease, the scales are weighted against them in such matters. The Medical Advisory Committee of the B.D.A. is helping to adjust the balance by preparing a form for adoption where one or both of the parents is diabetic. This form has been accepted for use by the Standing Conference of Societies
Registered for Adoption and may go a long way towards dispelling prejudices which have been entertained in the past and enabling the risks to be properly assessed.

\section{Diet}

At all ages difficulties with diet probably cause more problems than any one other factor in the diabetic picture. During my is years as Welfare Secretary of the British Diabetic Association, my correspondence-some 4,000 letters a year-and interviews have been chiefly concerned with diet problems: How can I choose a meal in a restaurant, attend a Lord Mayor's Banquet, celebrate Christmas or my wedding, take a picnic lunch to work or travel abroad? Some diabetics worry so much and are so fearful of their food-meticulous to the last gramme-that they are a nuisance to others and themselves; others, unable to grasp even the basic diet sheet, throw diet to the winds -and, of course, they do themselves harm, too. In the first group I remember a man who had been given the 'Simple Diabetic Diet (Unweighed).' He wrote and asked me to get him some scales marked in drams as he felt this would ensure better dietetic treatment than the doctor's prescription. In the second group is the lady who wrote with a certain gay abandon as a P.S. in a letter: " Can I eat cakes as well as calories?" An example comes to mind of lack of common-sense: a man on the railway, who had had seven ounces of onion every night for 12 years, wondered if it would be safe to have a bit of a change, his wife complained so of her daily cry over peeling them.

Neither the written nor the spoken word entirely solves their problems, but with visual aids we may have a means of helping many without stress or strain on their part. Playing cards, called 'Diet Without Tears,' depicting foods of known value in bright colours, have been devised as a visual aid in diet education. The quantities are, of course, approximate, as measures by eye must be; but the cards will give the diabetic a clear idea of the different types of foods-carbohydrate, protein and fat, and the amounts which may be interchanged. These cards can be used to play special versions of well-known games-Snap, Happy Families, Rummy and Housey-Houseyand all these games serve the same purpose, that of helping the diabetic to acquire a useful knowledge of food values with little or no conscious effort.

\section{Hypoglycaemia}

For most diabetics on insulin, hypoglycaemia is no more than an occasional inconvenience; but for those who are careless about the carbohydrate content and timing of meals or maintaining the 
necessary balance of extra exercise, insulin and carbohydrate, it can be a troublesome and sometimes serious liability. There are also some unfortunate diabetics who do not recognize early symptoms of insulin reaction and they must be careful to avoid situations in which a sudden attack could have dangerous consequences. For example, they should certainly be strongly advised not to apply for a driving licence. However, if the diabetic is well stabilized, always recognizes early symptoms of hypoglycaemia and is able to deal with it promptly and adequately, he can apply for a licence to drive a private car with a clear conscience and without declaring his diabetes.

\section{Old Age}

There are about 500,000 diabetics in Great Britain. Many of these are elderly, and of the aged diabetics the majority are likely to be women: some will be in the Elderly and Infirm group and the others in the Chronic Sick. The dividing line between these groups is very indistinct and will depend much on the patient's doctor. From the point of view of administration, however, this line is very clearly marked. The Elderly and Infirm are referred to in Part III of the National Assistance Act as "Persons who by reason of age, infirmity or any other circumstances, are in need of care and attention which is not otherwise available to them,' and the responsibility for their welfare rests on the local authority concerned. The Chronic Sick are served by the National Health Service Act and are primarily the responsibility of the Regional Boards. There is no statutory arrangement for co-operation between these two authorities and sometimes there may be difficulty in bridging the gulf.

Without exception all county authorities in Great Britain say they are prepared to accept elderly and infirm diabetics as residents in their homes, providing such cases are not chronic sick and are in need of care and attention. In the 12 homes run by the London County Council there are over 70 diabetics. However, beds for the elderly and infirm are far short of the general demand; in addition, in small homes where there is no trained staff, the care of the diabetic may prove difficult. In fact it is sometimes impossible to find accommodation for the diabetic in the ordinary old people's home. This being so, early in 1953 the British Diabetic Association established the first home for elderly diabetics in this country at Frederick Banting House, Kingston Hill, Surrey. Twenty-four of the residents are elderly and infirm and are maintained with the help of grants from the local authority originally responsible for each old person. A contribution from the Old Age Pension is also made, leaving ros. per week for the old person to spend. There are also nine beds for the aged classed as chronic sick, for whom the S.W. Metropolitan Regional Board accepts financial responsibility. The B.D.A. spent $£ 30,000$ in founding this home and, indeed, still spends a large sum every year on its upkeep: it considers the money well spent on such a project. In 1956 a second home, Charles Best House, Cheshire, was established in the north of England. At present this home cares for 26 elderly diabetics. Fortunately not all aged diabetics need to be in homes and there are many who bravely live alone, preferring independence, and others who happily, or sometimes unhappily, share in family life. The National Assistance Board is empowered at its discretion to help Old Age Pensioners who have inadequate means with the extra cost of diet: this allowance may amount to anything between $5 \mathrm{~s}$. and $5_{5} \mathrm{~s}$. per week.

There are, however, other difficulties than financial ones. As might be expected the majority of these old people have little or poor education, since in their childhood this was far more limited than nowadays. In old age, too, mental agility is not so great and it is indeed a problem for the health educationalists to teach the elderly diabetic the principles of treatment. Many prejudiceso habits and traditions may also stand in the way of education. A half century of these cannot be dispelled in a few minutes at the diabetic clinic. remember a story told by a professor of one of his new patients. She was an elderly housewife, diabetic, overweight. The professor took time and trouble explaining to her the principles of the diabetic diet. She listened intently and with patience. At the end of his homily she remarked: 'Well, all this is very interesting doctor, but you can't tell me a thing about food. You see, I've brought up I3 children.'

When the problems of finance and education have been tackled, there are still other and very important needs to consider. Old people particularly need love and kindness in their lives, someone to whom they can turn, someone to whom they are important. In welfare work with the old, therefore, one must be a good listener. It is time well spent to listen sympathetically to those who find the quick pace of present-day life disconcerting, and who like to talk, indeed to ramble on, in a leisurely way. Even if one can give no practical help and advice, the very act of talking often helps to dispel fears and worries.

There are now some 74 branches and clubs of the British Diabetic Association in the country, and it is one of their particular pleasures and duties to help the elderly diabetics in their areas. Visits, gifts, arrangements for parties, and even in some cases the financing of holidays are part of the 
personal service offered to the old. Undoubtedly the State does much for old people in providing what material comfort it can, and sometimes the personal touch creeps in: but it is obviously difficult for the machinery of State to provide this touch, and it is to local and voluntary efforts that we must turn. Branches and clubs may well be the means of contributing very largely to the relief of distress in the aged diabetic.
Old age can be a time of great unhappiness or of calm and contentment. These states are not en⿳亠丷厂 tirely dependent on physical health but may oftem be due to the withholding or giving of loving care. We must do all we can to help from the materiat. angle but, and this is important, we must also give that extra loving kindness which will do so muct to ensure a peaceful Indian summer for the age diabetic.

Bibliography continued from page $26_{5}-D$. A. Pyke, M.D., M.R.C.P.

HURWITZ, D., and JENSEN, D. (1946), New England F. Med., 234, 327.

JACKSON, W. P. U. (1955), Lancet, ii, 625.

JOHNSON, D. G., and BONSNES, R. W. (1948), F. clin. Invest., 27, 145 .

JOSLIN, E. P. (1952), in 'The Treatment of Diabetes,' London.

KEEN, H. (1957), Paper read to Banting Memorial Meeting of the British Diabetic Association, Oxford.

KEMSLEY, W. F. F. (1950), Ann. Eugen. (Lond.), 15, 161.

KEMSLEY, W. F. F. (1952), Ibid., 16, 316.

KRISS, J. P., and FUTCHER, P. H. (1948), J. clin. Endocr., 8, 380.

MOSENTHAL, H. O., and BOLDUAN, C. (1933), Amer. Y. med. Sci., 186, 605.

MUNRO, H. N., EATON, J. C., and GLEN, A. (1949), f. clin. Endocr., 9, 48.

PINCUS, G., and WHITE, P. (1933), Amer. F. med. Sci., 186, I.
PINCUS, G., and WHITE, P. (1934a), Ibid., 188, 159. PINCUS, G., and WHITE, P. (1934b), Ibid., 188, 782. PYKE, D. A. (1956), Lancet, i, 818.

PYKE, D. A., and PLEASE, N. W. (1957), f. Endocr., 15, xx PYKE, D. A., and WATTLEY, G. H. (1958), unpublishę

observations.
SEGI, M. (1956), 'Statistical Report on Patients in Tohok University Hospital, 1953-54,' Sendai, Japan.

STEINBERG, A. G. (1958), Diabetes, 7, 244.

THOMPSON, M. W., LAAKSO, L. E., and WATSON, E. Nis (1950), Canadian med. Ass. F., 63, 556.

TOMBLESON, S. B. (1954), N.Z. med. f., 53, 230.

WATSON, E. M., and THOMPSON, M. W. (1951), Amer. \& dig. Dis., 18, 326.

World Health Organization (W.H.O.) (1955), 'Annual Epidemio. logical and Vital Statistics, 1952.

Bibliography continued from page 280-Harry Keen, M.B., M.R.C.P.

HAND, B. H., and PATEY, D. H. (1953), Brit. F. Surg., 41, I6r. HANDELSMAN, M. B., LEVITT, L. M., and CONRAD, $H$. (1952), Amer. F. med.' Sci., 224, 34.

HICKAM, J. B., and PRYOR, W. W. (1951), F. clin. Invest., 30, 401 .

HIRSON, C., FEINMANN, E. L., and WADE, H. J. (1953), Brit. med. F., i, 1408 .

HODGES, F. R., RUNDLES, R. W., and HANELIN, J. (1947), Radiology, 49, 659 .

JANOWITZ, H. D., and GROSSMAN, M. I. (1950), F. invest. Derm., 14, 453.

JEFFERS, W. A., MONTGOMERY, H., and BURTON, A. C. (1941), Amer. F. med. Sci., 202, I.

JORDAN, W. R. (1936), Arch. intern. Med., 57, 307.

JORDAN, W. R., and CRABTREE, H. H. (I935), Ibid., 55, 17.

KASSANDER, P. (1958), Ann. intern. Med., 48, 797.

KEEN, H., FIELD, J. B., and JACKSON, D., to be published.

KERSLAKE, D. McK., and COOPER, K. E. (1950), Clin. Sci., 9, $3 \mathbf{I}$.

LEARMONTH, J. R. (I93I), Brain, 54, 147.

LEWIS, T. (1933), Clin. Sci., r, 175.

LISTER, J., and MAUDSLEY, R. H. (1951), Lancet, ii, I, I 10.

MACLEAN, E. R., and ALLEN, E. V. (1940), Ұ. Amer. Med. Ass., $115,2,162$.

MALINS, J. M., and FRENCH, J. M. (1957), Quart. f. Med., 26, 467 .

MARBLE, A. (1940), in ' Treatment of Diabetes Mellitus,' 7th Ed., Lea and Febiger, Philadelphia.

MARBLE, A. (1952), Ibid., 9th Ed.

MARTIN, M. M. (1952), 'M.D. Thesis,' Univ., Durham.

MARTIN, M. M. (1953), Lancet, i, 560.

MARTIN, M. M. (1953), Brain, 76, 594.

MEGIBOW, R. S., MEGIBOW, S. J., POLLACK, H., BOOKMAN, J. J., and OSSERMAN, K. (1953), Amer. $\mathcal{F}$. Med., 15, 322.

MENDLOWITZ, M., GROSSMAN, E. B., and ALPERT, S. (1953), Ibid., 15,316

MURI, J. W. (1953), Acta med. scand., 146, 143.

NAUNY, B. N. (1906), in 'Der Diabetes Mellitus,' and Ed., Holder, Vienna.

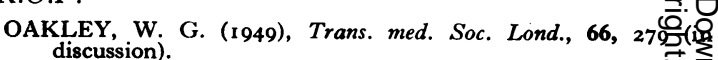

OAKLEY, W., CATTERALL, R. C. F., and MARTIN, M. NG (1956), Lancet, ii, 953. ODEL, H. M., ROTH, G. M., and KEATING, F. R. (I95悉
Diabetes, 4, 92 .

PARSONS, H., and NORTON, W. S. (r95I), New Engl. Y. Med 244, 935 .

PAVY, W. F. (1885), Lancet, ii, 1,033 and $\mathrm{r}, 085$.

PICKERING, Sir G. W. (r958), Ibid., i, I and 59.

ROOT, H. F., and KENNY, A. J. (r952), in ' Treatment of Diabetes Mellitus,' 9 th Ed., Lea and Febiger, Philadelphia.

RUBIN, A., and BABBOTT, D. (1958), F. Amer. med. Ass., r68 498.

RUDY, A., and MUELLNER, R. S. (194I), F. Urol (Baltimoref 45,844 .

RUNDLES, R. W. (1945), Medicine (Baltimore), 24, I I I.

RUNDLES, R. W. (1950), Bull. N.Y. Acad. Med., 26, 598.

SHEPPE, W. M. (1953), Ann. intern. Med., 39, 625.

SHERIDAN, E. P., and BAILEY, C. C. (I946), 7 Amer med Ass I30, 623.

SHUMACKER, H. B. (1942), Bull. Fohns Hopk. Hosp., 71, I.

SHUMAN, C. R., and GILPIN, S. F. (1954), Amer. F. med. ScII 227, 612.

SIMPSON, S. L. (1950), Brit. med. F., i, 692.

SMIRK, F. H. (1957), ' High Arterial Pressure,' Blackwell Scientiffe Publications, Oxford.

SMITH, H. W. ( 195 I), 'The Kidney,' Oxford University Press.

SMITH, M. D. (1949), Glasg. med. F., 30, 18 I.

SPRING, M., and HYMES, J. (1953), Diabetes, 2, 199.

STRAUSS, E. B. (1950), Brit. med. F., i, 697

SWARTS, J. M., and STINE, L. A. (1948), Amer. Y. Med., 5, 6 ro

VEREL, D. (195I), Brit. Heart F., 13, 6r.

WAFTE, J. H., and BEETHAM, W. P. (1935), New Engl. F. Med 212, $367,429$.

WHITE, J. C., and SMITHWICK, R. H. (1944), 'The Autonomi Nervous System,' 2nd Ed., Kimpton, London. WILKINS, R. W., NEWMAN, H. W., and DOUPE, J. (1939
Brain, 6I, 290.

WOLTMAN, H. W., and WILDER, R. M. (1929), Arch. inters Med., $44,576$. 